To be published in Effects of Radiation on Materials, 18th International Symposium, ASTM STP 1325, R. K. Nanstad, M. L. Hamilton, F. A. Garner, and A. S. Kumar, Eds., American Society for Testing and Materials, 1997.

$$
\text { CONF- } 960643-
$$

\title{
USE OF FORCES FROM INSTRUMENTED CHARPY V-NOTCH TESTING TO DETERMINE CRACK-ARREST TOUGHNESS
}

S. K. Iskander, ${ }^{1}$ R. K. Nanstad, ${ }^{1}$ M. A. Sokolov, ${ }^{1}$

D. E. McCabe, ${ }^{1}$ J. T. Hutton, ${ }^{2}$ and D. L. Thomas ${ }^{2}$

Metals and Ceramics Division

\section{OAK RIDGE NATIONAL LABORATORY}

P.O. Box 2008

Oak Ridge, TN 37831-6151

RECEIVED

JUN 101998

QSTI

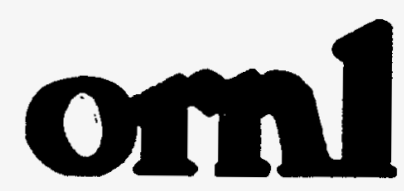

${ }^{1}$ Metals and Ceramics Division, Oak Ridge National Laboratory, P.O. Box 2008, Oak Ridge, TN 37831-6151, managed by Lockheed Martin Energy Research Corporation under contract DE-AC05-96OR22464 for the U.S. Department of Energy.

${ }^{2}$ Instrumentation and Controls Division, Oak Ridge National Laboratory.

The submitted manuscript has been authored by a contractor of the U.S. Government under contract No. DE-AC05-96OR22464. Accordingly,

the U.S. Government retains a nonexclusive. royalty-free license to publish or reproduce the published form of this contribution, or allow others to do so, for U.S. Government purposes. 


\section{DISCLAIMER}

This report was prepared as an account of work sponsored by an agency of the United States Government. Neither the United States Government nor any agency thereof, nor any of their employees, makes any warranty, express or implied, or assumes any legal liability or responsibility for the accuracy, completeness, or usefulness of any information, apparatus, product, or process disclosed, or represents that its use would not infringe privately owned rights. Reference herein to any specific commercial product, process, or service by trade name, trademark, manufacturer, or otherwise does not necessarily constitute or imply its endorsement, recommendation, or favoring by the United States Government or any agency thereof. The views and opinions of authors expressed herein do not necessarily state or reflect those of the United States Government or any agency thereof. 
S. K. Iskander, ${ }^{1}$ R. K. Nanstad, ${ }^{1}$ M. A. Sokolov, ${ }^{1}$ D. E. McCabe, ${ }^{1}$ J. T. Hutton, ${ }^{2}$ and D. L. Thomas ${ }^{2}$

\section{USE OF FORCES FROM INSTRUMENTED CHARPY V-NOTCH TESTING TO DETERMINE CRACK-ARREST TOUGHNESS}

REFERENCE: Iskander, S. K., Nanstad, R. K., Sokolov, M. A., McCabe, D. E., Hutton, J. T., and Thomas, D. L. "Use of Forces from Instrumented Charpy V-notch Testing to Determine Crack-arrest Toughness," Effects of Radiation on Materials: 18th International Symposium, ASTM STP 1325, R. K. Nanstad, M. L. Hamilton, F. A. Garner, and A. S. Kumar, Eds., American Society for Testing and Materials, 1997.

ABSTRACT: The objective of this investigation is an estimation of the crack-arrest toughness, particularly of irradiated materials, from voltage versus time output of an instrumented tup during a test on a Charpy V-notch (CVN) specimen. This voltage versus time trace (which can be converted to force versus displacement) displays events during fracture of the specimen. Various stages of the fracture process can be identified on the trace, including an arrest point indicating arrest of brittle fracture. The force at arrest, $F_{2}$ versus test temperature, $T$, relationship is examined to explore possible relationships to other experimental measures of crack-arrest toughness such as the drop-weight nil-ductility temperature (NDT), or crack-arrest toughness, $\mathrm{K}_{\mathbf{2}}$. For a wide range of weld and plate materials, the temperature at which $\mathrm{F}_{\mathrm{z}}=2.45 \mathrm{kN}$ correlates with NDT with a standard deviation, $\sigma$, of about $11 \mathrm{~K}$. Excluding the so-called "low upper-shelf energy" (USE) welds from the analysis resulted in $\mathrm{F}_{\mathrm{a}}=4.12 \mathrm{kN}$ and $\sigma=6.6 \mathrm{~K}$. The estimates of the correlation of the temperature for $F_{2}=7.4 \mathrm{kN}$ with the temperature at $100-\mathrm{MPa} \cdot \sqrt{\mathrm{m}}$ level for a mean American Society of Mechanical Engineers (ASME) type $\mathrm{K}_{\mathrm{b}_{\mathbf{2}}}$ curve through crack-arrest toughness values show that prediction of conservative values of $K_{a}$ are possible.

KEYWORDS: instrumented Charpy, crack-arrest toughness, nil-ductility transition temperature, NDT, irradiation embrittlement, reactor pressure vessel steels

${ }^{1}$ Metals and Ceramics Division, Oak Ridge National Laboratory, P.O. Box 2008, Oak Ridge, TN 37831-6151, managed by Lockheed Martin Energy Research Corp. under contract DE-AC05-960R22464 for the U.S. Department of Energy.

${ }^{2}$ Instrumentation and Controls Division, Oak Ridge National Laboratory. 


\section{INTRODUCTION}

In the fracture mechanics integrity analysis of reactor pressure vessels (RPVs), the initiation and arrest fracture toughness curves, the $\mathrm{K}_{\mathrm{lc}}$ and $\mathrm{K}_{\mathrm{la}}$ curves, respectively, as described in Sect. XI of the ASME Boiler and Pressure Vessel Code, are often used. The $\mathrm{K}_{\mathrm{th}}$ curve is also used for the normal operation of RPVs. The effects of neutron irradiation on toughness are accounted for by shifting the curves upward in temperature without change in shape by an amount equal to the temperature shift of the CVN impact energy curve at the $41-\mathrm{J}$ level $\left(\Delta \mathrm{TT}_{41-\mathrm{J}}\right)$. Such a procedure implies that the shifts in the fracture toughness curves are the same as those of the Charpy $\Delta \mathrm{TT}_{41 \cdot \mathrm{s}}$ and that irradiation does not change the shapes of the fracture toughness curves. Moreover, according to current applications, the $34-\mathrm{K}$ margin at the $100 \mathrm{MPa} \cdot \checkmark \mathrm{m}$ level between the unirradiated ASME $\mathrm{K}_{\mathrm{Ic}}$ and $\mathrm{K}_{\mathrm{L}}$ curves is assumed to be preserved after irradiation to the same fluence (Fig. 1).

It is well known that irradiation of some RPV ferritic steels to fluences on the order of $2 \times 10^{19} \mathrm{n} / \mathrm{cm}^{2}(>1 \mathrm{MeV})$ can cause changes in the shape of the CVN impact energy curve. Research programs have been sponsored by the U.S. Nuclear Regulatory Commission (NRC) within the Heavy-Section Steel Irradiation (HSSI) Program at Oak Ridge National Laboratory (ORNL) to determine whether similar changes in shape can occur in the fracture toughness curves, particularly if such changes could lead to nonconservative determinations of the irradiated fracture toughness. Such nonconservative values of fracture toughness were indeed observed for some irradiated initiation fracture toughness values, $\mathrm{K}_{\mathrm{Jc}}[1]$.

Recall that the ASME $\mathrm{K}_{\mathrm{Ic}}$ and $\mathrm{K}_{\mathrm{fa}}$ curves shown in Fig. 1 are lower bounds to the data and are separated by $34 \mathrm{~K}$ at the $100-\mathrm{MPa} \cdot \sqrt{\mathrm{m}}$ level. In Fig. 2 , the irradiated $\mathrm{K}_{\mathrm{Jc}}$ and $\mathrm{K}_{\mathrm{a}}$ [2] values for HSSI weld $73 \mathrm{~W}$ [3] have been combined in a single plot. The average fluence is $1.5 \times 10^{19} \mathrm{n} / \mathrm{cm}^{2}(>1 \mathrm{MeV})$ for the $\mathrm{K}_{\mathrm{Jc}}$ specimens and $1.9 \times 10^{19} \mathrm{n} / \mathrm{cm}^{2}$ $(>1 \mathrm{MeV})$ for the $\mathrm{K}_{\mathrm{Ia}}$ specimens. Also shown on the same figure is the ASME $\mathrm{K}_{\mathrm{Ic}}$ curve calculated for an $\mathrm{RT}_{\mathrm{NDT}}$ of $47^{\circ} \mathrm{C}$. It is of interest to note that for HSSI weld $73 \mathrm{~W}$, the results of irradiated drop-weight specimens testing gave a value of the nil-ductility transition (NDT) temperature of $46^{\circ} \mathrm{C}$, and the shift in the $41-\mathrm{J}$ indexed temperature is $81 \mathrm{~K}$. When the $41-\mathrm{J}$ shift is added to the unirradiated NDT temperature of $-34^{\circ} \mathrm{C}$, the resulting $\mathrm{RT}_{\mathrm{NDT}}$ is $47^{\circ} \mathrm{C}$, which agrees very well with the irradiated drop-weight NDT temperature. Also to be noted is that the drop-weight NDT temperature dictated the determination of $\mathrm{RT}_{\mathrm{NDT}}$ in accordance with Subarticle NB-2330 of the 1995 edition of the ASME Boiler and Pressure Vessel Code, Section III. In Fig. 2, the ASME $\mathrm{K}_{\mathrm{I}_{2}}$ curve has been plotted with an adjusted reference temperature (ART), instead of an $\mathrm{RT}_{\mathrm{NDT}}$, of $59^{\circ} \mathrm{C}$, to account for the higher irradiation fluence of the crack-arrest specimens. It is recognized that there is some inconsistency since the toughness values have not been normalized to a single fluence. Nonetheless, the difference in fluences has been noted on the Fig. 2. A lower-bound curve shown as a dashed line was obtained by shifting the ASME $K_{\mathrm{L}}$ curve to lower temperatures by approximately $39 \mathrm{~K}$ until it encounters the first toughness value, either $\mathrm{K}_{\mathrm{Jc}}$ or $\mathrm{K}_{2}$. Note that the lower bounds to the irradiated $\mathrm{K}_{\mathrm{Jc}}$ and $\mathrm{K}_{\mathrm{a}}$ 


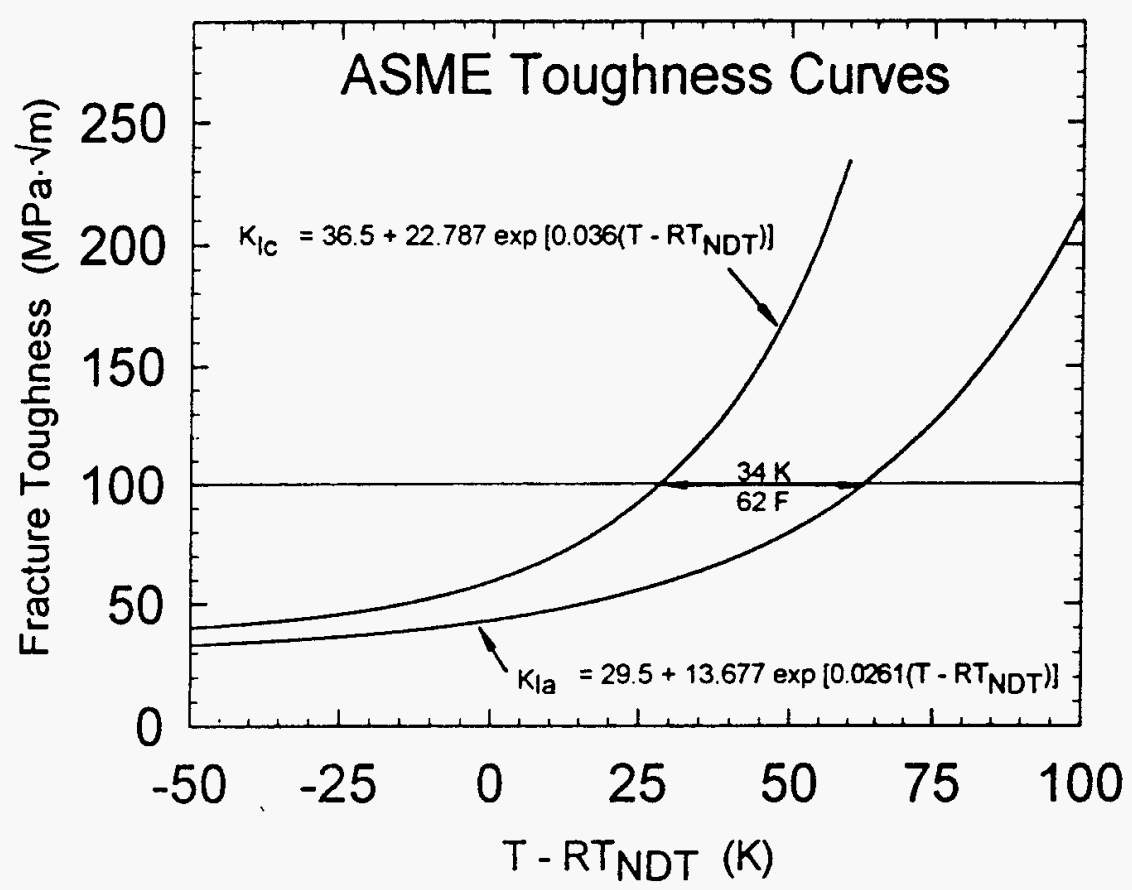

FIG. 1--A 34-K margin at the $100 \mathrm{MPa} \cdot \sqrt{\mathrm{m}}$ level between the unirradiated ASM: $\mathrm{K}_{\mathrm{Ic}}$ and $\mathrm{K}_{\mathrm{ta}}$ curves is assumed to be preserved after irradiation to the same fluence.

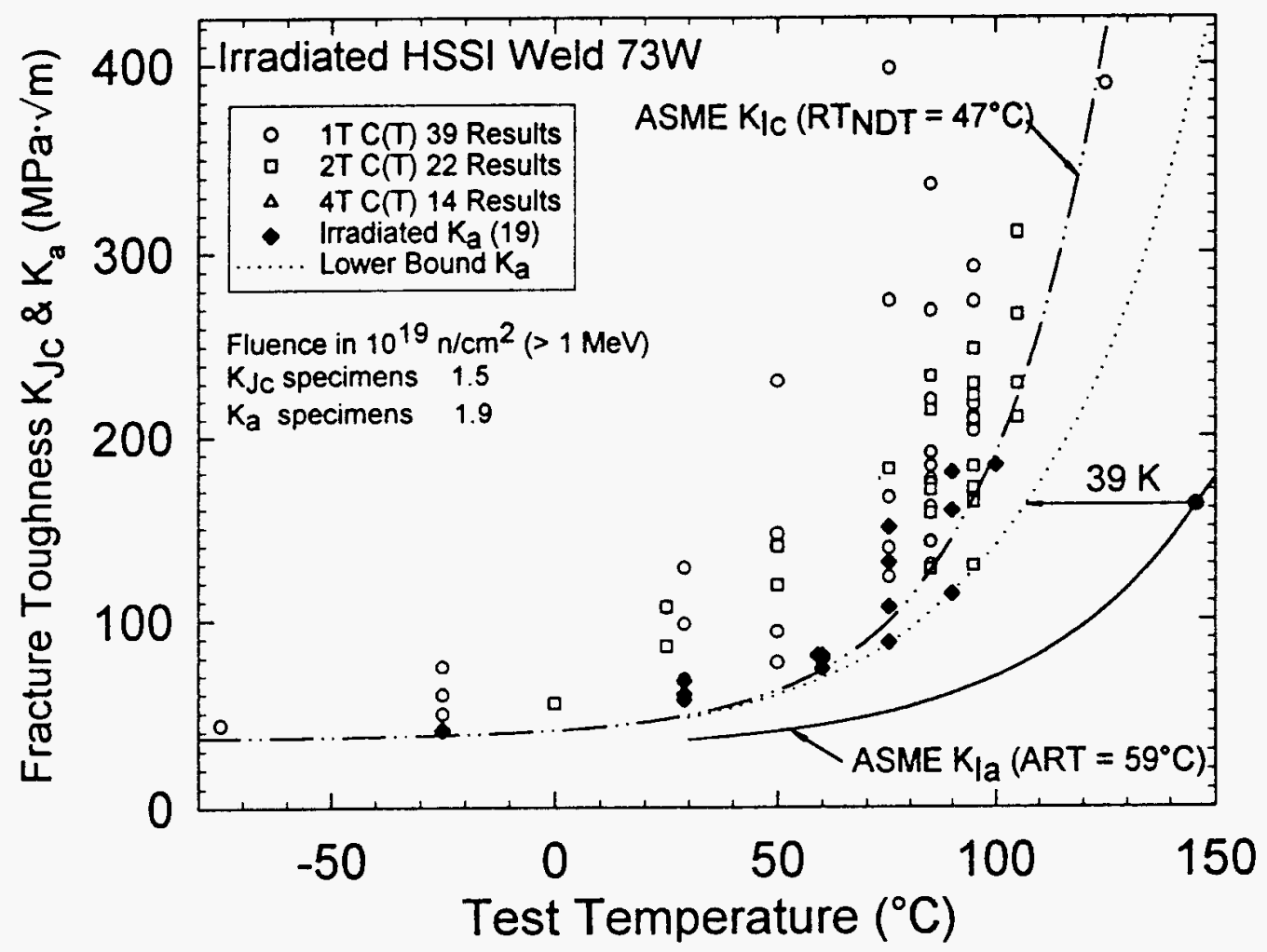

FIG. 2--Lower bounds to the irradiated $\mathrm{K}_{\mathrm{Jc}}$ and crack-arrest toughness values, $\mathrm{K}_{\mathrm{a}}$, for the same HSSI weld 73W nearly coincide, but still show a $39-\mathrm{K}$ margin to the ASME $\mathrm{K}_{\mathrm{ta}}$ curve. 
for HSSI weld $73 \mathrm{~W}$ nearly coincide. It should also be noted that the lower bound to the fracture toughness has been measured using fewer crack-arrest specimens (19) compared to the compact tension specimens (75). Thus, in cases where lower-bound irradiated toughness values are required, there is some merit in the use of crack-arrest toughness rather than crack initiation.

Crack-arrest testing of irradiated specimens is both difficult and expensive, thus it is worthwhile exploring a proxy for the determination of crack-arrest toughness. An attractive approach would be to use information already available from instrumented CVN testing. In this paper, two approaches were examined, assuming that the reference temperature $\mathrm{RT}_{\mathrm{NDT}}$ is the same as the drop-weight nil-ductility transition temperature, NDT. In the first, the correlation between NDT and the temperature at a certain value of arrest force, as obtained from an instrumented Charpy notch trace, was explored; this would be useful in cases for which an NDT is not available. If such a correlation exists, then an estimate for the drop-weight NDT (NDT Estimated $_{\text {) }}$ could be used in a similar manner as the $\mathrm{RT}_{\mathrm{NDT}}$ is used to index crack-arrest toughness, $\mathrm{K}_{\mathrm{a}}$ :

$$
\mathrm{K}_{\mathrm{a}}=29.5+13.677 \exp \left[0.0261\left(\mathrm{~T}-\mathrm{T}_{\text {Estimated }}\right)\right] \text {, }
$$

where, for unirradiated materials, $\mathrm{T}_{\text {Essimuted }}=\mathrm{NDT}_{\text {Estimated. }}$. In the case of irradiated materials:

$$
\mathrm{T}_{\text {Estimated }}=\mathrm{NDT}_{\text {Estimated }}+\mathrm{ART}_{41-\mathrm{J}} \text {, }
$$

where $\mathrm{ART}_{41-\mathrm{J}}=$ adjusted 41-J CVN transition temperature, as obtained, e.g., from surveillance tests. The advantage of such an approach for irradiated materials is that it involves the presently used concept of transition temperature shift for indexing $\mathrm{K}_{2}$ and would only require instrumented traces for the unirradiated material and the $\mathrm{ART}_{41 \mathrm{~J} \cdot \mathrm{J}}$. For HSSI welds $72 \mathrm{~W}$ and $73 \mathrm{~W}$, the shift between the mean curves through the experimentally obtained unirradiated and irradiated $\mathrm{K}_{\mathrm{a}}$ values was approximately the same as the $\mathrm{ART}_{41-\mathrm{J}}$. Moreover, a margin of over $25 \mathrm{~K}$ exists between the lower-bound curves to the data and the ASME $K_{L_{2}}$ curve [2].

The arrest force, $F_{2}$, is assumed to be a material property in the same sense as the NDT temperature. The NDT temperature is determined according to the American Society for Testing and Materials (ASTM) Test for Conducting Drop-Weight Test to Determine Nil-Ductility Transition Temperature of Ferritic Steels (E 208-91). It is also considered a measure of a material's ability to arrest a crack propagating in a highly stressed field.

The second approach explores the correlation between the temperature, $T_{100}$, at the $100 \mathrm{MPa} \cdot \sqrt{\mathrm{m}}$ level of the mean curve through experimental $\mathrm{K}_{2}$ values, and the temperature, $\mathrm{T}^{*}{ }_{100}$, for an average value of $\mathrm{F}_{2}$. Such an approach has the merit that it 
bypasses the correlations between fracture toughness, NDT, and transition temperature shifts, since it could be used in the same manner as $T_{\text {Estimsted }}$ in Eq. (1).

The materials studied were chosen to cover a wide range of drop-weight NDT, and a summary of their mechanical properties is shown in Table 1. Included are weld and plate materials with NDTs ranging from -60 to $60^{\circ} \mathrm{C}$, and low and high USEs ranging from 60 to $330 \mathrm{~J}$. Note in particular the 15-K range of NDT values measured from different locations in the Midland welds. For purposes of this analysis, average values of -53.1 and $-47.4^{\circ} \mathrm{C}$ for the beltline and nozzle materials, respectively [4], were used for correlating $F_{a}$ with NDT.

\section{DROP-WEIGHT NDT AND ARREST LOADS FROM INSTRUMENTED CVN TRACES}

Many investigators have already explored correlations between $\mathrm{F}_{2}$, as determined from the load-displacement trace deduced from an instrumented CVN tup, and the NDT temperature. Vasoukis has performed extensive analysis of the load-displacement trace and has suggested the NDT could be correlated to the temperature at which the $\mathrm{F}_{\mathrm{a}}=0$, Ref. [5]. In an another investigation, Schoch observed that $F_{a}=3 \mathrm{kN}$ correlated better with the NDT [6]. In a more recent study by Wallin, $F_{a}=4 \mathrm{kN}$ was chosen as a transition criterion [7]. McCabe et al. have suggested that a so-called $\left(\mathrm{T}_{0}\right)_{\mathrm{a}}$ temperature be determined from the following equation [ $[\underline{]}$ :

$$
\left(\mathrm{T}_{0}\right)_{\mathrm{I2}}=\mathrm{T}_{\mathrm{F} 4}-10^{\circ} \mathrm{C} \text {, }
$$

where $T_{F 4}$ is the temperature at an arrest load at $F_{2}=4 \mathrm{kN}$.

This paper attempts to obtain as much information from the CVN impact test as possible, since it plays an important role in much of the NRC-sponsored research performed at ORNL, primarily because of its relationship to the determination of the $\mathrm{RT}_{\mathrm{NDT}}$ for both unirradiated and irradiated RPV steels. Although the ASME fracture initiation and arrest toughness curves, $\mathrm{K}_{\mathrm{Ic}}$ and $\mathrm{K}_{\mathrm{I}}$ and related toughness values determined by fracture mechanics-based tests are the basis for integrity assessments, the Charpy test provides much valuable information because of its simplicity. Moreover, it has been generally recognized for some time that the load-deflection record obtained from the test can yield much valuable information on material behavior. A study of the effect of temperature on various fracture parameters in instrumented Charpy and slow-bend tests on fatigue precracked and standard Charpy specimens machined from Heavy-Section Steel Technology (HSST) Program Plate 01 in the L-T orientation was performed and reported in early 1970 [2]. The fracture parameters considered were the load at general yield, maximum load, fast-fracture initiation, and fast-fracture arrest. The energy absorbed and deflection before and after the previously mentioned loads were also investigated. Among the observations from a similar study on a submerged-arc weldment is that for the temperature range -18 to $260^{\circ} \mathrm{C}\left(0\right.$ to $\left.500^{\circ} \mathrm{F}\right)$, the energy absorbed to general yield and to 
TABLE 1--Mechanical properties of eight materials studied.

\begin{tabular}{|c|c|c|c|c|c|}
\hline \multirow[t]{2}{*}{ Material } & \multirow{2}{*}{$\begin{array}{c}\text { Drop- } \\
\text { weight NDT } \\
\left({ }^{\circ} \mathrm{C}\right)\end{array}$} & \multirow{2}{*}{$\begin{array}{l}\text { CVN } \\
\text { impact } \\
\text { USE } \\
(J)\end{array}$} & \multirow{2}{*}{$\begin{array}{l}\text { CVN 41-J } \\
\text { transition } \\
\text { temperature } \\
\left({ }^{\circ} \mathrm{C}\right)\end{array}$} & \multicolumn{2}{|c|}{$\begin{array}{l}\text { Room temperature } \\
\text { tensile strength } \\
(\mathrm{MPa})\end{array}$} \\
\hline & & & & Yield & Ultimate \\
\hline HSSI weld $72 W^{a}$ & -23 & 118 & -38 & 489 & 606 \\
\hline HSSI weld $73 W^{a}$ & -34 & 135 & -40 & 490 & 599 \\
\hline Midland beltline weld ${ }^{b}$ & -45 to $-60^{c}$ & 78 to $108^{d}$ & -22 to 14 & 407 & 586 \\
\hline Midland nozzle weld & -40 to $-55^{\prime}$ & 85 to $90^{\prime}$ & -11 to 5 & 505 & 655 \\
\hline Hope Creek RPV weld & -50 & 125 & -46 & - & - \\
\hline $\begin{array}{l}\text { HSST Plate } 14 \\
\text { (A533B1) }\end{array}$ & -20 & 181 & -6 & 394 & 555 \\
\hline $\begin{array}{l}\text { Wide Plate WP-CE } \\
\text { (A533B1) }\end{array}$ & -35 to -40 & 330 & -62 to -38 & 400 & 540 \\
\hline $\begin{array}{l}\text { Wide Plate Series } 2^{h} \\
(2.25 \mathrm{Cr}-1 \mathrm{Mo} \text { special heat } \\
\text { treatment) }\end{array}$ & 55 to $60^{i}$ & 61 to 65 & 90 to 96 & 307 & 597 \\
\hline \multicolumn{6}{|c|}{ 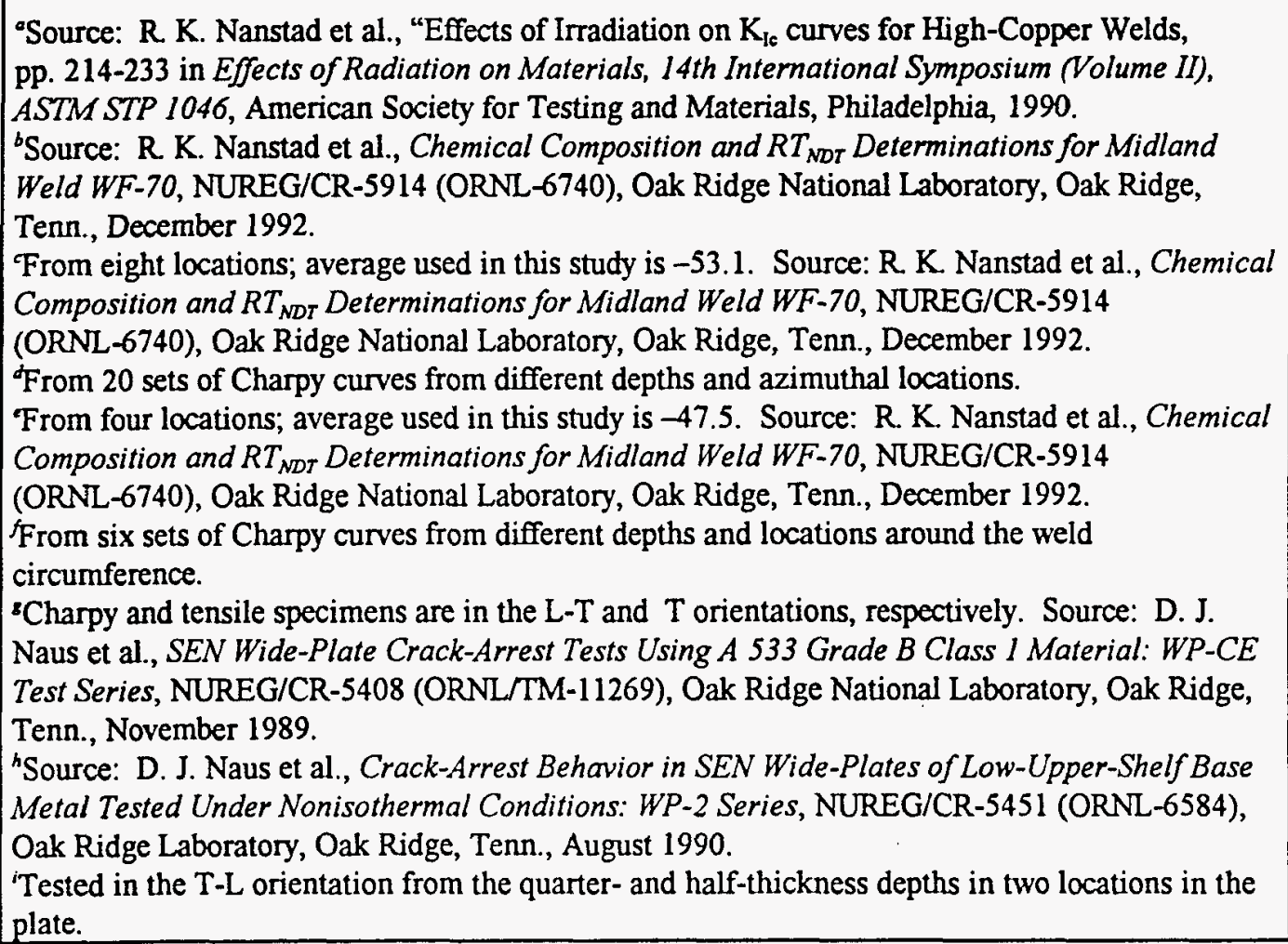 } \\
\hline
\end{tabular}


maximum load were independent of temperature and were 5.4 and $52 \mathrm{~J}$ ( 4 and $38 \mathrm{ft}-\mathrm{lb}$ ), respectively [10].

It has been standard practice at ORNL for many years to record the voltage output from the instrumented tup from all CVN testing and store that output on magnetic media. This provides the flexibility to reanalyze the trace at a later time, e.g., when new standard methods on instrumented CVN impact testing are issued. ${ }^{3,4}$ The stored output from archival testing could then be reanalyzed to take advantages of the advances in this area.

A typical load-displacement trace from an instrumented test on a specimen machined from the Midland beltline weld and tested at $-25^{\circ} \mathrm{C}$ is shown in Fig. 3. The trace was captured by recording 4096 data points of voltage output of the sensor in an ASTM E 23 tup of the Charpy tester. The voltage was recorded by a $4095 \mathrm{C}$ digital oscilloscope and a 4570 storage control unit (both manufactured by Nicolet). The tup is instrumented with a solid state sensor (Dynatup Products, General Research Corp.). The excitation voltage was $5 \mathrm{VDC}$, and the maximum output is nominally $1 \mathrm{VDC}$. The digital data from the oscilloscope are then recorded on a computer disk.

The characteristics of the amplifier used to amplify the voltage output of the instrumented tup in dynamic events are important. The characteristics of the commercial amplifier previously used were unsatisfactory, so one was designed and fabricated by ORNL; the amplitude attenuation is shown in Fig. 4 as a function of the frequency. The data shown in Fig. 4 were obtained by injecting a calibrated signal of known voltage and frequency directly into the amplifier, then measuring the amplitude of the output. The frequency scale in Fig. 4 is logarithmic; if the frequency scale were linear, then amplitude attenuation shown would be linear. It should be noted that the amplitude attenuation at $100 \mathrm{kHz}$ is approximately $7 \%$, which is acceptable. If the signal from the tup contained data whose frequency were higher than $1 \mathrm{MHZ}, 100 \%$ of the signal would be lost and the output would not reflect their contributions to the amplitude. Whether the contributions of frequencies higher than $100 \mathrm{kHZ}$ are significant or not cannot be determined unless an amplifier capable of handling the higher frequencies is built and tested (ORNL has plans to design and build such an amplifier).

The captured trace of the instrumented Charpy tup is converted from volts versus time to force versus displacement by using the kinetic and dynamic relationships between acceleration, velocity, and dial energy. It is assumed that the voltage output, $\mathrm{V}$, from the instrumented tup is proportional to the force, $F$, on the tup, thus $F=K V$, where $K$ is a

${ }^{3}$ One proposed standard method for instrumented CVN impact testing is being evaluated by the working party "European Standards on Instrumented Charpy Testing" of the European Structural Integrity Society (ESIS).

${ }^{4}$ ASTM Subcommittee E28.07 is also considering an annex to the Standard E 23 that addresses instrumented impact testing, similar to the ESIS proposal. 


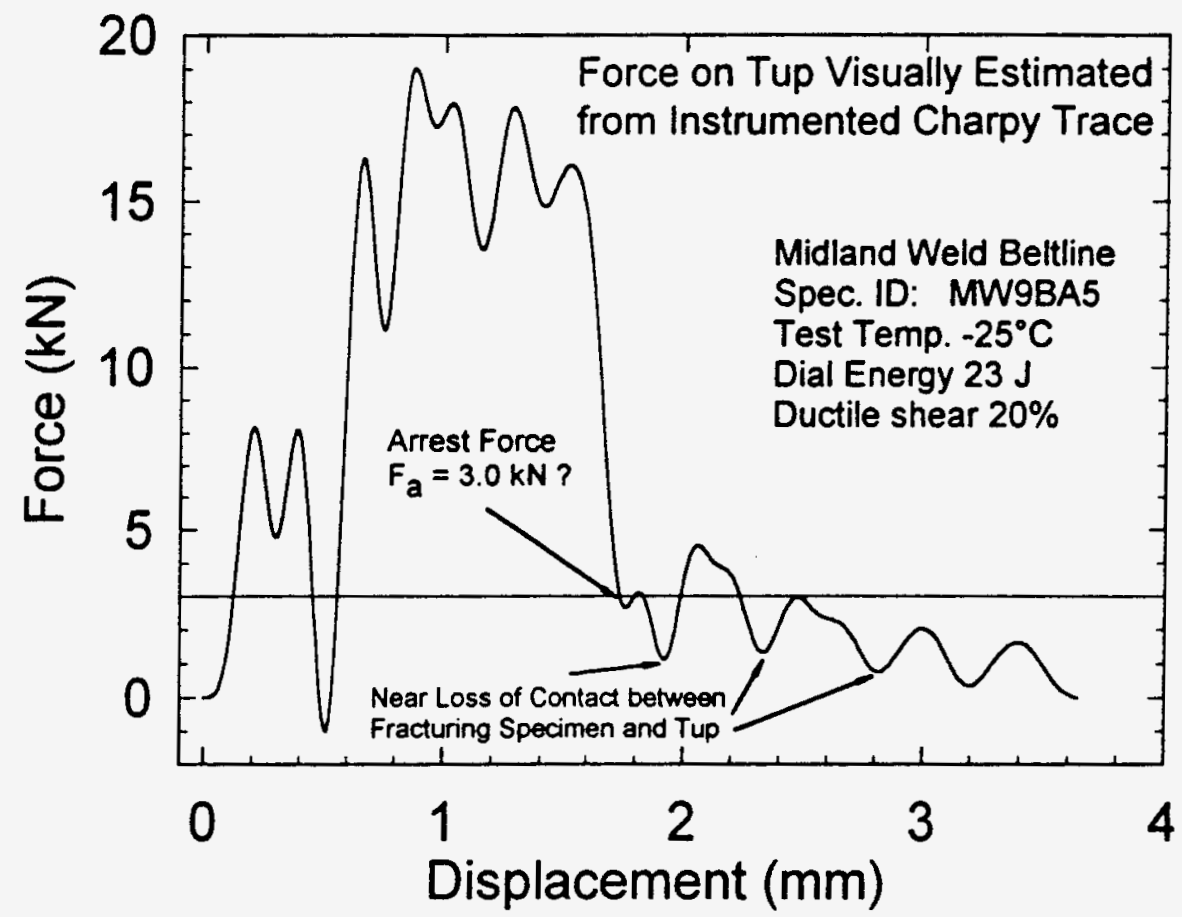

FIG. 3--Load versus displacement trace deduced from voltage versus time output of an instrumented ASTM E 23 CVN tup.

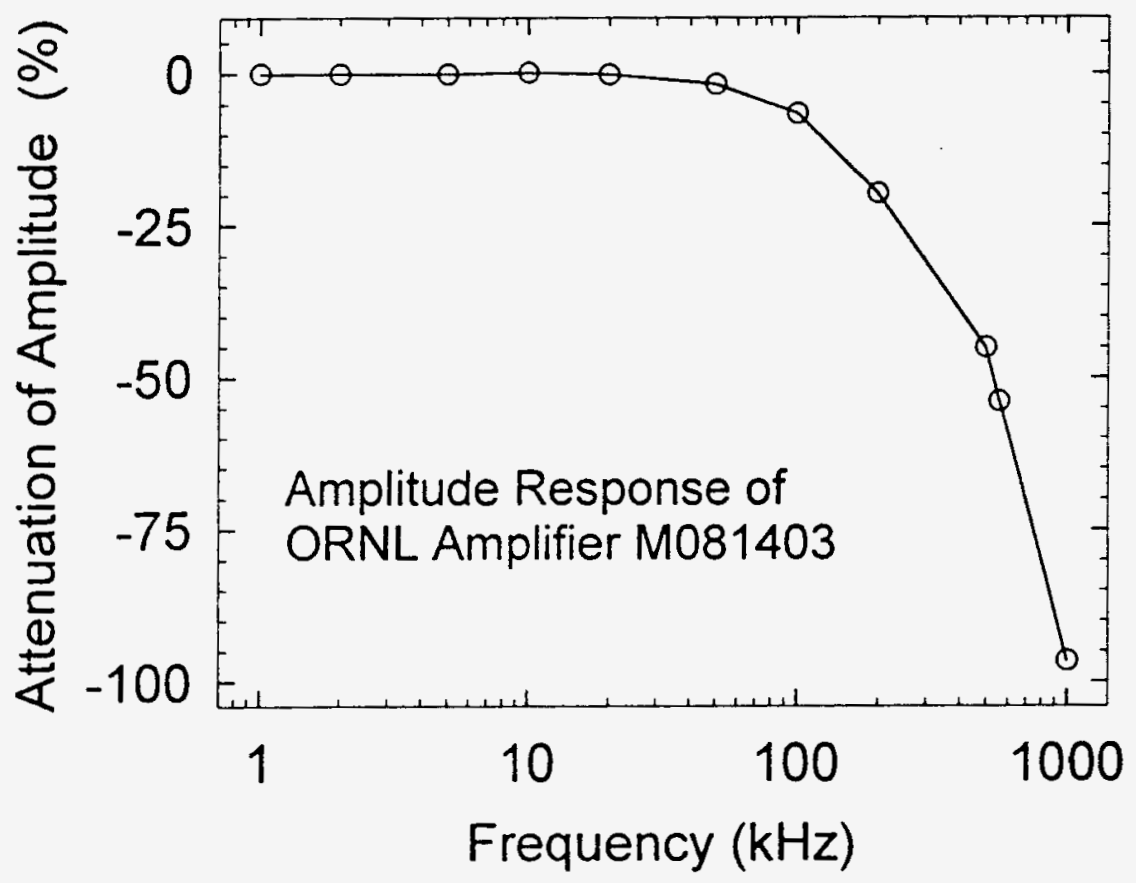

FIG. 4--Frequency-dependent amplitude attenuation for ORNL tup amplifier M081403. The function generator signal is fed directly into the amplifier. 
calibration constant. Using $\mathrm{F}=\mathrm{ma}$, where $\mathrm{m}$ is the mass of the Charpy pendulum and the acceleration is "a." Thus,

$$
a=K \frac{V}{m} .
$$

Furthermore, it is assumed that the dial energy indicated by the Charpy machine is equal to the line integral of the force $F$ and the path of the pendulum. It is recognized that F may not register all forces that contribute to the dial energy, such as the specimen rebounding into the noninstrumented areas of the pendulum or tup; it is assumed that such contributions, when they occur, are small relative to the total dial energy. By numerically integrating Eq. (4) with respect to time, using the output $V$ of the instrumented tup consisting of the relationship between voltage and time, results in a velocity versus time relationship. The constant of integration is evaluated using the known velocity $v_{0}$ of the tup just before impact. Using the well known relationship between change in kinetic energy, $m\left(v_{0}{ }^{2}-v\right) / 2$ and work done; namely dial energy, it is possible to determine $\mathrm{K}$. A second integration will give the displacement-to-time relationship, which, together with the force-to-time relationship, produces a force-to-displacement relationship, such as the one shown in Fig. 3.

The advantage of the above procedure is that, except for $m$ and $v_{0,}$ all the information necessary for determining $\mathrm{K}$ is in the voltage/time record. The value of $\mathrm{K}$ has also been determined by statically determining the maximum force necessary to break a material that is relatively strain-rate insensitive, such as aluminum, both statically and dynamically. The static test is performed using a three-point bend fixture of the same geometry as the Charpy tup and anvils. The static test yields the maximum force in Newtons, and from the maximum voltage recorded during the dynamic (Charpy) test, it is possible to determine $\mathrm{K}$. The value of $\mathrm{K}$ from both procedures agrees well with each other. The disadvantage of the static/dynamic procedure is that it is difficult to assess the strain-rate insensitivity of the material used, and the value of $\mathrm{K}$ is associated with a particular anvil, instrumentation parameters, e.g., the excitation voltage, amplifier, etc., must be recorded with each test.

The arrest force, $F_{v}$ is determined visually with the aid of computer graphics. The value of $F_{2}$ requires some engineering judgement from the analyst, particularly the experience gained in performing many crack-arrest tests. As an aid to the analyst, the force at the intersection of two smoothing curves fit to both the fast fracture and post fast fracture portions of the load-displacement curve could be used as $F_{2}$. Such a procedure may not be the optimum method to determine $\mathrm{F}_{\mathrm{a}}$. Among the reasons for the limited success of using the intersection point to determine $F_{2}$ may be multiple fast run-arrest events, loss of contact between the tup and the specimen followed by contact and dynamic noise, followed by tearing (Fig. 3). Fitting of a curve to the various segments of the load-displacement trace still requires judgement with regard to the end points of the segments to use in the fit. As mentioned previously, the value of $F_{2}$ was determined visually using engineering judgement, rather than the intersection of a fast fracture and the 
tearing curves as in the proposed annex to ASTM E 23. The determination of $\mathrm{F}_{2}$ in a more consistent method requires further study.

The value of $\mathrm{F}_{2}$ is based on Charpy data and consequently reflects the scatter of Charpy testing. The following four smoothing functions were fit to the $\mathrm{F}_{2}$ versus test temperature, $\mathrm{T}$, data:

$$
\begin{gathered}
F_{a}=\frac{a+b}{2}+\frac{a-b}{2} \tanh \left(\frac{T-c}{d / 2}\right), \quad b \geq 0, \\
F_{a}=a+b \exp \left(\frac{T}{b}\right), \quad a \geq 0, \\
F_{a}=a \exp \left(\frac{T}{b}\right), \\
F_{a}=a+b T
\end{gathered}
$$

where a, b, c, and d are fitting parameters. The choice of the tanh function in Eq. (5) is suggested by the frequent use of this function to fit Charpy test results. The exponential functions in Eqs. (6) and (7) are suggested by the ASME curve for $\mathrm{K}_{\mathrm{Lr}}$. Note the form of Eq. (5) and (6) allows $\mathrm{F}_{2}$ to have an asymptotic value which is constrained to be $\geq 0$, similar to the asymptotic value in the ASME equation for $\mathrm{K}_{\mathrm{L}}$. Equation (8) is for a straight line, the simplest one that could be fit to the data. The choice of which function was "best" was guided by the following procedure. All four functions were fit to the data of all materials studied, and $F_{2}$ is determined at NDT using each of the functions. The values of $F_{2}$ for all the materials were then averaged for each of the functions. Using the average $F_{2}$, the value of NDT for each of the materials is then estimated, and the error between the estimate and the actual value is determined. The function that gave the smallest sum of the square of the errors (SSE) was judged as being the best one to use. Table 2 shows the results from this procedure, and the tanh function gave the smallest SSE. A plot comparing the estimated and actual NDT together with the $\pm 2 \sigma$ margins, were $\sigma$ is the standard deviation, is shown in Fig. 5. The value of $\sigma$ for the error in estimated NDT using the tanh function is $11.2 \mathrm{~K}$. Experience with the $\mathrm{E} 208$ drop-weight test showed that the value of NDT, determined strictly according to E 208, could have a

\footnotetext{
${ }^{5}$ Evidence of an asymptotic value of $\mathrm{F}_{\mathbf{z}}$ was observed for some materials.
} 
TABLE 2--Force at NDT for all materials studied, square of error between actual and estimated values.

\begin{tabular}{||l|c|c|c|c|c||}
\hline \multirow{2}{*}{ Material } & \multirow{2}{*}{$\begin{array}{c}\text { Drop-weight } \\
\text { NDT } \\
\left({ }^{\circ} \mathrm{C}\right)\end{array}$} & \multicolumn{3}{|c|}{ Load $(\mathrm{kN})$ at NDT obtained by fitting the data using } \\
\cline { 3 - 6 } & $\begin{array}{c}\text { Hyperbolic } \\
\text { tanh }\end{array}$ & $\begin{array}{c}\text { Asymptotic } \\
\text { exponential }\end{array}$ & Exponential & Linear \\
\hline HSSI weld 72W & -23 & 3.3 & 3.3 & 3.4 & 4.4 \\
HSSI weld 73W & -34 & 2.7 & 2.9 & 2.9 & 4 \\
Midland beltline weld & -53.1 & 1.2 & 2.7 & 3.4 & 3.2 \\
Midland nozzle weld & -47.5 & 1.7 & 1.6 & 2.7 & 1.2 \\
Hope Creek RPV weld & -50 & 2.18 & 4.9 & 5.2 & 4.8 \\
HSST Plate 14 & -20 & 2.6 & 3.7 & 3.7 & 4.3 \\
Wide Plate CE Series & -36.25 & 3 & 3.84 & 3.9 & 3.9 \\
Wide Plate Series 2 & 57.5 & 2.9 & 3 & 2.7 & 3.3 \\
\hline Average force & & 2.45 & 3.24 & 3.49 & 3.64 \\
Coefficient of variance & & 0.29 & 0.30 & 0.23 & 0.31 \\
Sum of squared errors & & 900 & 1166 & 2275 & 955 \\
\hline
\end{tabular}


scatter in values of NDT of at least $\pm 5 \mathrm{~K}$ or even $\pm 10 \mathrm{~K}$, and error bars are shown in Fig. 5 to reflect such scatter.

An example of the fit of the four functions to the $F_{2}$ versus $T$ data is shown in Fig. 6(a). Figure 6(b) shows Charpy energy versus $T$ for the same material to illustrate the scatter of Charpy data, particularly near the value of NDT $\left(-34^{\circ} \mathrm{C}\right)$ which is the subject of the correlation.

The correlation can be improved significantly by excluding the Midland beltline and nozzle materials, and could be justified as follows. For both the Midland beltline and nozzle welds, a large range of NDTs were measured, depending on the location of the material in the vessel weld. For these welds, using the average value of NDT shown in Table 1 resulted in $F_{2}=1.2$ and $1.7 \mathrm{kN}$, respectively, which are anomalously lower than the average of $4.12 \mathrm{kN}$ for the remaining materials (see Table 2 and Fig. 7). Note that by using the highest measured value of NDT would have improved the correlation significantly. Excluding the Midland beltline and nozzle results from the averaging process resulted in an average of $F_{z}=4.12$, and reduced $\sigma$, of the error to $6.6 \mathrm{~K}$. The comparison of estimated to actual NDT is shown in Fig. 8, together with the $\pm 2 \sigma$ margins. It may be seen that the estimate of NDT is excellent for the four materials near the middle range of NDTs, but is still good at the extreme ends of the NDT range examined. Table 3 shows the average force associated with each function, and the errors in estimated NDT when the average force/function is used. In this case, the linear function gave the smallest SSE.

The average $\mathrm{F}_{2}$ at the temperature that corresponds to a mean $\mathrm{K}_{2}$ level of $100 \mathrm{MPa} \cdot \sqrt{\mathrm{m}}$ has been determined for materials in both the unirradiated and irradiated conditions, and is shown in Table 4 using the following method. A mean $\mathrm{K}_{2}$ versus $\mathrm{T}$ curve, similar in form to Eq. (1), was fit to the experimental crack-arrest toughness results from several previous ORNL studies [2][11][12][13] and using $T_{\text {Mean }}$ (instead of $T_{\text {Estimated }}$ ) as the fitting parameter. The temperature, $T_{100}$, at which the mean $K_{2}=100 \mathrm{MPa} \cdot \sqrt{\mathrm{m}}$ is then determined. The force, $F_{2}$ at the temperature, $T_{100}$, is then determined for each of the materials from their $F_{2}$ versus $T$ relationships. These forces are then averaged, and resulted in an average $F_{2}=7.40 \mathrm{kN}$. Using this average value, the temperature $T^{*}{ }_{100}$, was estimated using the function ${ }^{6}$ that best fit the data. The "best-fit" function is the one giving largest value of " $r$," a measure of the goodness of fit.

The values of $\mathrm{K}_{\mathrm{a}}$ versus normalized test temperature, $\mathrm{T}-\mathrm{T}^{*}{ }_{100}$, have been plotted in Fig. 9, which indicates that the relationship between $K_{2}$ and the relevant temperature from the Charpy test is reasonable. It is not believed that the scatter in $\mathrm{K}_{2}$ values is unusual, since much scatter is observed even for the same material in fracture toughness testing of RPV steels. The single $\mathrm{K}_{\mathrm{a}}$ value for the Hope Creek weld that lies on the ASME $K_{l_{2}}$ curve was below the ASME $K_{l_{2}}$ curve for that material in the $K_{2}$ versus test

${ }^{6}$ In most cases the values of $\mathrm{F}_{\mathrm{a}-100}$ and $\mathrm{T}^{*}{ }_{100}$ estimated using either of the "best-fit" functions did not vary significantly. 


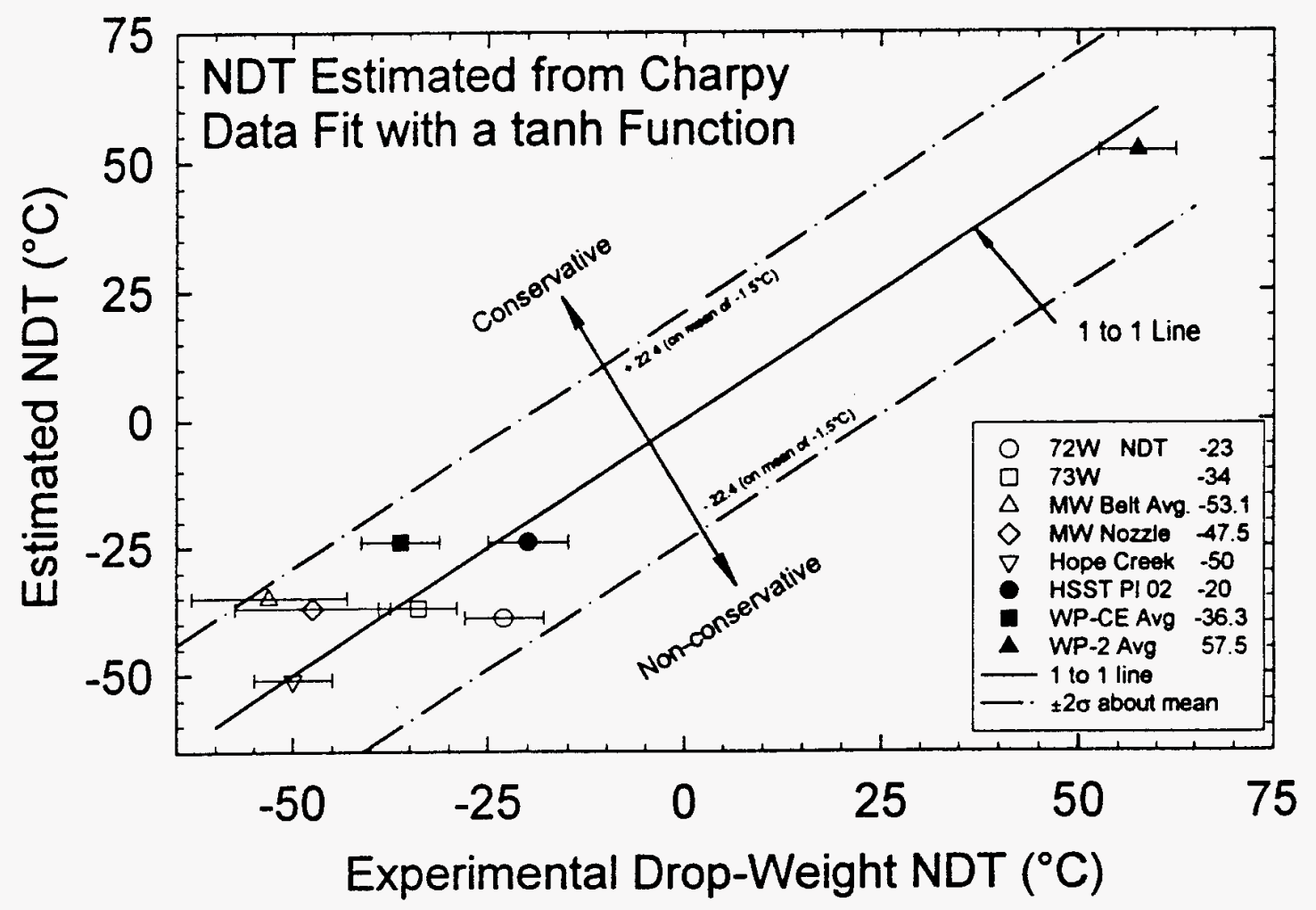

FIG. 5--Comparison of estimated and actual NDT values for all the materials studied.

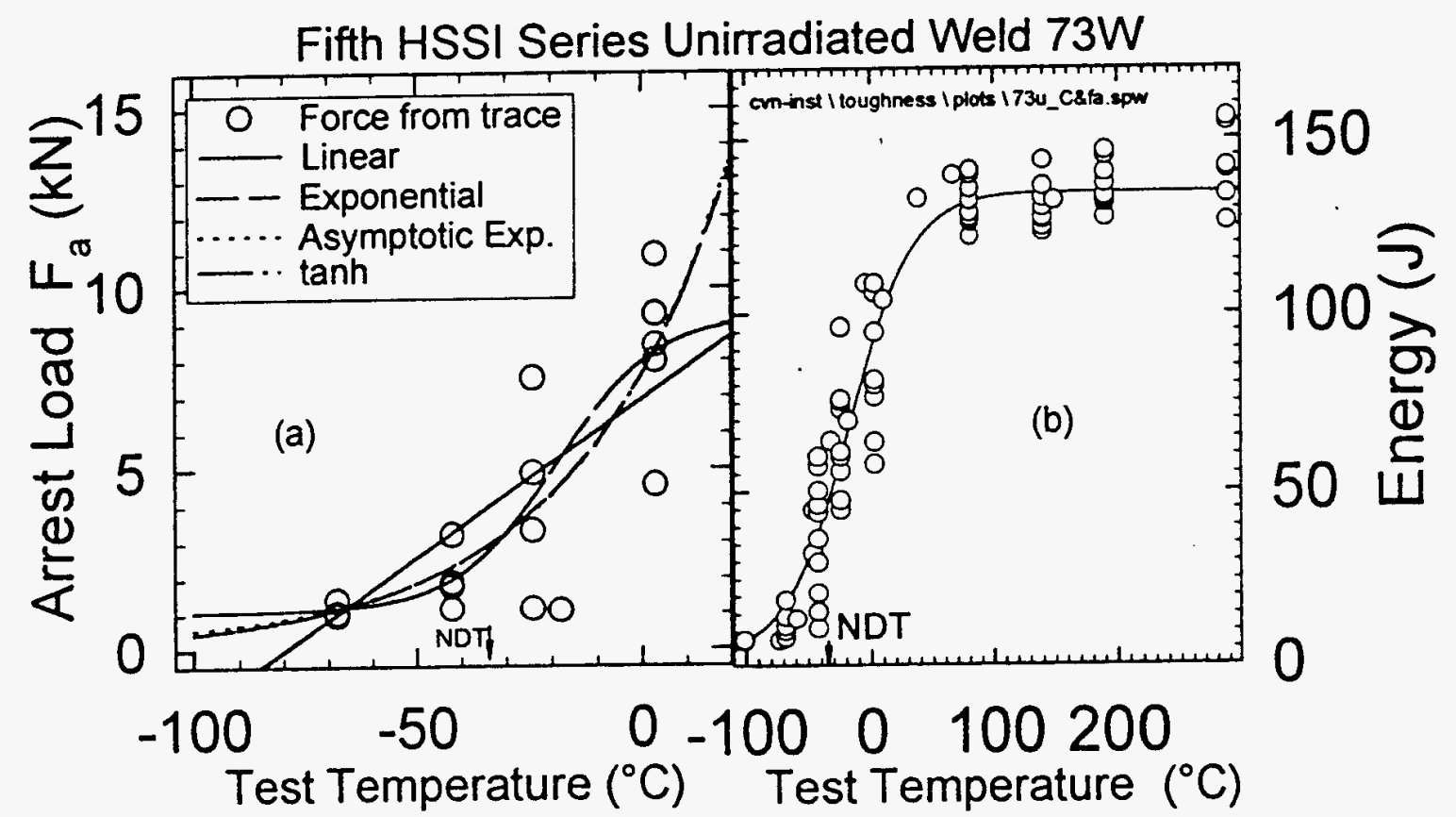

FIG. 6--Charpy results for HSSI weld 73W showing (a) comparison of the fit of four functions to arrest force $F_{a}$ and (b) scatter in impact energy, particularly near NDT. 

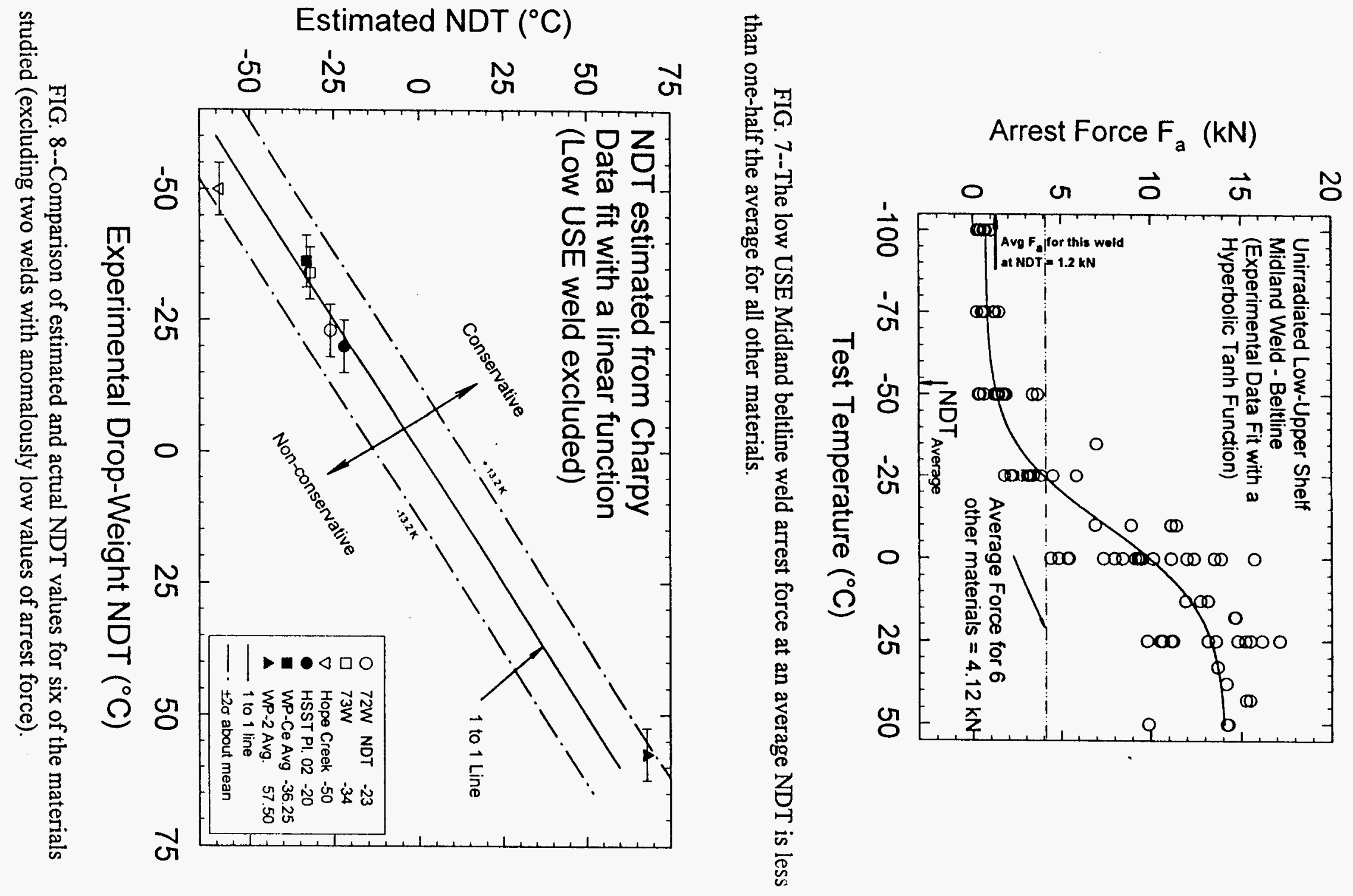
TABLE 3--Comparison of the error in NDT values for six materials studied (excluding the low USE weld) when different smoothing functions were used.

\begin{tabular}{||l|c|c|c|c|c||}
\hline \multirow{2}{*}{ Material } & \multirow{2}{*}{$\begin{array}{c}\text { Drop-weight } \\
\text { NDT } \\
\left({ }^{\circ} \mathrm{C}\right)\end{array}$} & $\begin{array}{c}\text { Eyperbolic } \\
\text { tanh }\end{array}$ & $\begin{array}{c}\text { Asymptotic } \\
\text { exponential }\end{array}$ & Exponential & Linear \\
\cline { 3 - 6 } & & 2.78 & 3.61 & 3.63 & 4.12 \\
\hline Average arrest force & -23 & 9 & -4 & -2 & 3 \\
\hline HSSI weld 72W & -34 & 0 & -8 & -8 & -2 \\
HSSI weld 73W & -50 & 9 & 17 & 36 & 9 \\
Hope Creek RPV weld & -20 & -2 & 1 & 1 & 2 \\
HSST Plate 14 & -36.25 & 8.75 & 3.75 & 4.75 & -3.25 \\
Wide Plate CE Series & 57.5 & 1.5 & -7.5 & -12.5 & -10.5 \\
Wide Plate Series 2 & & 244.8 & 440.3 & 1543.8 & 218.8 \\
\hline Sum of squares of errors & & &
\end{tabular}


TABLE 4--Various temperatures and forces estimated from the mean crack-arrest fracture toughness and Charpy arrest force relationships.

\begin{tabular}{|c|c|c|c|c|c|}
\hline Material & $\mathrm{T}_{\text {Mean }}^{a}$ & $\begin{array}{l}\mathrm{T}_{100}{ }^{b} \\
\left({ }^{\circ} \mathrm{C}\right)\end{array}$ & $\begin{array}{l}\mathrm{F}_{\mathrm{a}-100^{c}} \\
(\mathrm{kN})\end{array}$ & $\begin{array}{l}\mathrm{T}^{*}{ }^{100}{ }^{d} \\
\left({ }^{\circ} \mathrm{C}\right)\end{array}$ & $\begin{array}{l}\text { Best-fit } \\
\text { function }\end{array}$ \\
\hline $\begin{array}{l}\text { HSSI weld } 72 \mathrm{~W} \text {, unirradiated } \\
\text { HSSI weld } 73 \mathrm{~W} \text {, unirradiated }\end{array}$ & $\begin{array}{l}-72.3 \\
-74.0\end{array}$ & $\begin{array}{r}-9.5 \\
-11.2\end{array}$ & $\begin{array}{l}4.48 \\
6.51\end{array}$ & $\begin{array}{l}10 \\
-5\end{array}$ & $\begin{array}{l}\text { Asymptotic exponential, Eq. (6) } \\
\text { tanh, Eq. (5) }\end{array}$ \\
\hline HSSI weld $72 \mathrm{~W}$, irradiated & 11.7 & 74.5 & 9.54 & 64 & Exponential, Eq. (7) \\
\hline HSSI weld $73 \mathrm{~W}$, irradiated & 6.0 & 68.8 & 9.05 & 49 & Linear, Eq. (8) \\
\hline Midland beltline weld, unirradiated & -71.7 & -8.8 & 7.83 & -10 & $\tanh$, Eq. (5) \\
\hline Hope Creek weld & -78.7 & -15.9 & 9.49 & -33 & $\tanh$, Eq. (5) \\
\hline Wide plate Series 2 & 15.3 & 78.1 & 4.92 & 109 & Linear, Eq. (8) \\
\hline \multicolumn{3}{|l|}{ Mean $F_{2-100}(k N)$} & 7.40 & & \\
\hline \multicolumn{6}{|c|}{ 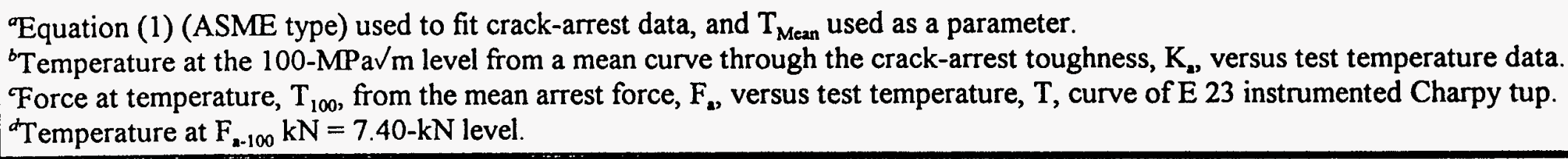 } \\
\hline
\end{tabular}




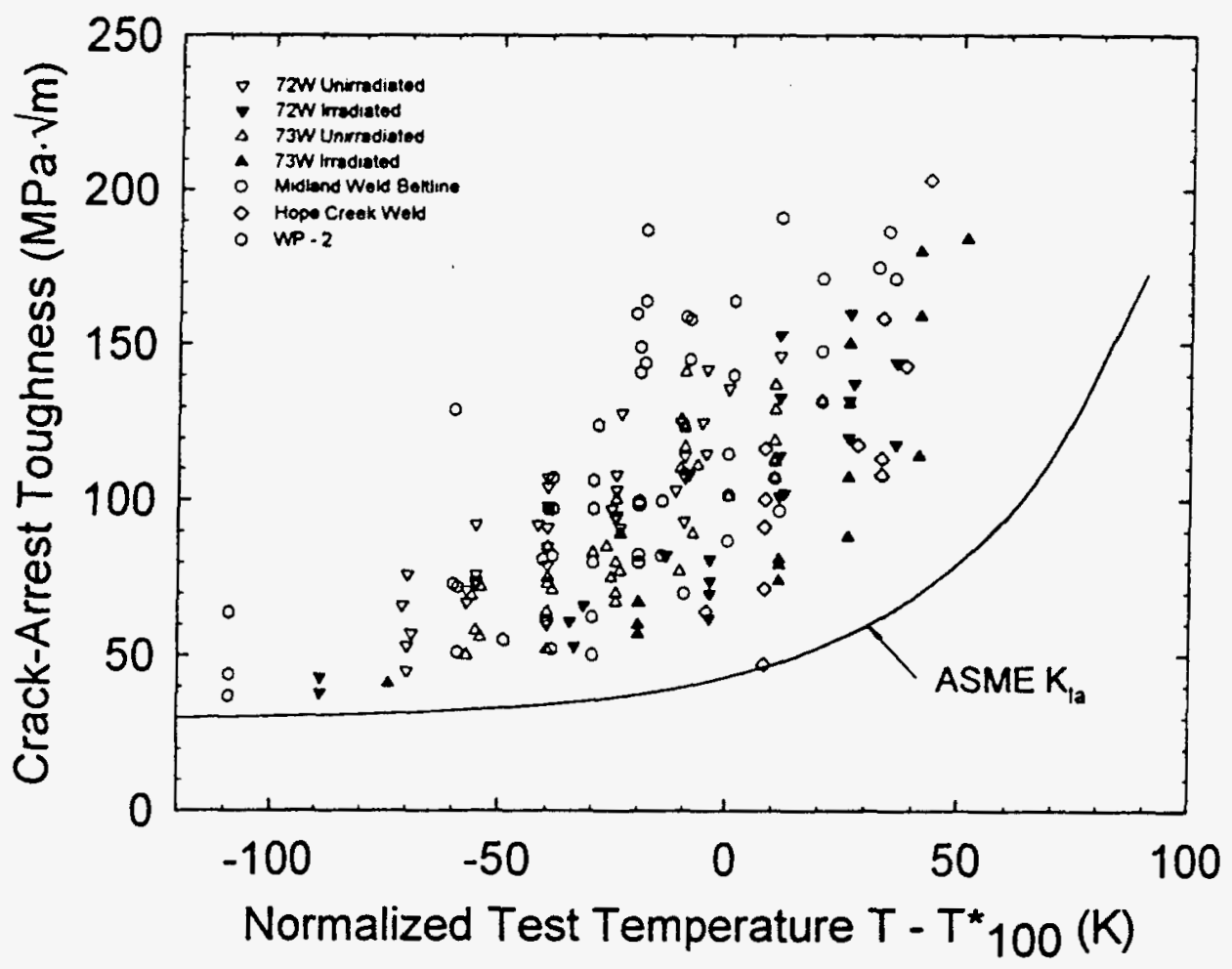

FIG. 9--Crack-arrest toughness values of various materials normalized using a temperature estimated from the Charpy arrest force.

temperatures plot, and is not a consequence of the procedure used in this paper. More significantly is the almost $30 \mathrm{~K}$ of conservatism between the results and the ASME $\mathrm{K}_{\mathrm{Lz}}$ curve. The advantage of this method is that this will allow for a mean conservative $\mathrm{K}_{2}$ curve to be estimated directly from the Charpy arrest force, $F_{2}$. As mentioned above, this bypasses correlations between NDT, Charpy shifts, and the crack-arrest toughness.

\section{SUMMARY AND CONCLUSIONS}

Eight materials with known properties were used to explore whether a correlation existed between various measures of arrest toughness. The objective was to use the arrest force, $\mathrm{F}_{2}$, obtained from an instrumented ASTM E 23 Charpy tup during a test on a standard $10 \times 10 \times 55 \mathrm{~mm} \mathrm{CVN} \mathrm{specimen} \mathrm{as} \mathrm{the} \mathrm{basis} \mathrm{for} \mathrm{deducing} \mathrm{the} \mathrm{drop-weight} \mathrm{NDT}$ and the temperature at which the crack-arrest toughness is $100 \mathrm{MPa} \cdot \sqrt{\mathrm{m}}$ on a mean curve through experimentally determined crack-arrest toughness values, $K_{\mathbf{a}}$. The following observations were made:

1. It is possible to estimate a mean conservative crack-arrest toughness curve from arrest forces of an instrumented ASTM E 23 Charpy tup.

2. The temperature for an arrest force, $F_{2}=2.45$, for all materials studied correlated reasonably with the drop-weight nil-ductility transition temperature, NDT, to a standard deviation, $\sigma=11.2 \mathrm{~K}$. 
3. If the two materials with a large variation in NDT are excluded, the temperature for an average $F_{a}=4.12 \mathrm{kN}$ for remaining six of the materials correlated well with the drop-weight NDT with a standard deviation, $\sigma=6.6 \mathrm{~K}$. Experience with the drop-weight test suggests that the error in NDT is about $\pm 5 \mathrm{~K}$, and can be more. The measured NDTs of the two excluded materials each varied $15 \mathrm{~K}$.

4. Determination of the value of $\mathrm{F}_{2}$ from Charpy testing is not straightforward, since it needed some engineering judgement in estimating its value. A more consistent method for determining arrest force is being studied.

5. The voltage versus time trace from the instrumented tup could be influenced by the amplitude attenuation characteristics of the instrumentation. A tup amplifier with $5 \%$ attenuation at $1 \mathrm{MHz}$ is being designed to determine if amplitude attenuation is a significant variable.

\section{ACKNOWLEDGMENTS}

This research is sponsored by the Office of Nuclear Regulatory Research, U.S. Nuclear Regulatory Commission, under Interagency Agreement DOE 1886-8109-8L with the U.S. Department of Energy under Contract No. DE-AC05-96OR22464 with Lockheed Martin Energy Research Corp. The authors would like to thank

David J. Alexander and the ASTM reviewers for peer review and Julia L. Bishop for preparation of the manuscript.

\section{REFERENCES}

[1] Nanstad, R. K., McCabe, D. E., Menke, B. H., Iskander, S. K., and Haggag, F. M., "Effects of Irradiation on $\mathrm{K}_{\mathrm{Ic}}$ curves for High-Copper Welds," pp. 214-233 in Effects of Radiation on Materials, 14th International Symposium, (Volume II), ASTM STP 1046, N. H. Packan, R. E. Stoller, and A. S. Kumar, Eds., American Society for Testing and Materials, Philadelphia, 1990.

[2] Iskander, S. K., Corwin, W. R., and Nanstad, R. K., Nanstad, "Effects of Irradiation on Crack-Arrest Toughness of Two High-Copper Welds," pp. 251-269 in Effects of Radiation on Materials: 15th International Symposium, ASTM STP 1125, R. E. Stoller, A. S. Kumar, and D. S. Gelles, Eds., American Society for Testing and Materials, Philadelphia, 1992.

[3] Iskander, S. K., Corwin, W. R., and Nanstad, R. K., "Effects of Irradiation on Crack-Arrest Toughness of Two High-Copper Welds," pp. 251-269 in Effects of Radiation on Materials: 15th International Symposium, ASTM STP 1125, R. E. Stoller, A. S. Kumar, and D. S. Gelles, Eds., American Society for Testing and Materials, Philadelphia, 1992. 
[4] Nanstad, R. K., McCabe, D. E., Swain, R. L., and Miller, M. K., Chemical Composition and $R T_{N D T}$ Determinations for Midland Weld WF-70, NUREG/CR-5914 (ORNL-6740), Oak Ridge National Laboratory, Oak Ridge, Tenn., December 1992.

[5] Vasoukis, G. "Fraktographie und Analyse der Kerbschlagbiegeversuchs" (Doctoral Dissertation), Universität Stuttgart, 1971.

[6] Schoch, F-W, "Eigenschaften formgeschweisster Grossgauteile: Werkstoffuntersuchungen an einem $72 \mathrm{t}$ Versuchskörper aus Schweissgut 10MnMoNi55" (Doctoral Dissertation), Universität Stuttgart, 1984.

[7] Wallin, K., Descriptive Potential of Charpy-V Fracture Arrest Parameter with Respect to Crack Arrest $K_{\text {Ia }}$ VTT-MET B-221, Metals Laboratory, Technical Research Centre of Finland, Espoo, Finland, January 1993.

[ ] McCabe, D. E., Nanstad, R. K., Iskander, S. K., and Swain, R. L., Unirradiated Material Properties of Midland Weld WF-70, NUREG/CR-6249 (ORNL/TM-12777), Oak Ridge National Laboratory, Oak Ridge, Tenn., October 1994.

[9] Berggren, R. G., Stelzman, W. J., and Jones, T. N., "Studies of Impact and SlowBend Charpy-Type Specimens," pp. 20-30 in Heavy-Section Steel Technology Program Semiann. Prog. Rep. for Period Ending February 28, 1970, ORNL-4590, Oak Ridge National Laboratory, Oak Ridge, Tenn., October 1970.

[10] Stelzman, W. J., and Berggren, R. G., Fig. 14 in Radiation Strengthening and Embrittlement in Heavy-Section Steel Plates and Welds, ORNL-4871, Oak Ridge National Laboratory, Oak Ridge, Tenn., June 1973.

[11] Iskander, S. K., Corwin, W. R., and Nanstad, R. K., Crack-Arrest Tests on Two Irradiated High-Copper Welds. Phase II: Results of Duplex-Type Specimens, NUREG/CR-6139 (ORNL/TM-12513), Oak Ridge National Laboratory, Oak Ridge, Tenn., March 1994.

[12] McCabe, D. E., Nanstad, R. K., Iskander, S. K., and Swain, R. L., Unirradiated Material Properties of Midland Weld WF-70, NUREG/CR-6249 (ORNL/TM-12777), Oak Ridge National Laboratory, Oak Ridge, Tenn., October 1994.

[13] Naus, D. J., Keeney-Walker, J., Bass, B. R., Robinson, Jr., G. C., Jr., Iskander, S. K., Fields, R. J., deWit, R., Low, S. R., Schwartz, C. W., Alexander, D. J., and Johansson, I.-B., Crack-Arrest Behovior in SEN Wide-Plates of Low-Upper-Shelf Base Metal Tested Under Nonisothermal Conditions: WP-2 Series, NUREG/CR-5451 (ORNL-6584), Oak Ridge National Laboratory, Oak Ridge, Tenn., August 1990. 
M98005642

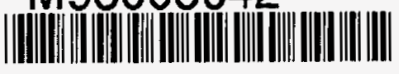

Report Number (14) ORNL/CP_-927/7

CONF- 960643 -.

Publ. Date (11) $199 \stackrel{6}{106}$

Sponsor Code (18) NRC/RES, XF

UC Category (19) UC-000, DOE/ER

19980702035

DTHC QUATHS DTSPECTHD 1

DOE 